\title{
Determination of baseline Widal titre among apparently healthy population in Dehradun City
}

\author{
Dr.Vijay K Kataria ${ }^{1}$, Dr. Niti Bhai ${ }^{2}$, Dr. Bhim S Mahawal ${ }^{1}$, \\ Dr. Reshmi C Roy ${ }^{1}$ \\ ${ }^{I}$ (Department of Microbiology,SGRRIM \& HS, Patel Nagar Dehradun. Uttarakhand, India) \\ ${ }^{2}$ (Regency Hospital, Kanpur,India)
}

\begin{abstract}
Present study was conducted to determine the baseline widal titer of healthy population of Dehradun city. A total of 300 serum samples were collected from healthy individual with no history of fever and who had not received any vaccination for enteric fever. Tube agglutination test was done with commercially available antigens which contained the Salmonella enterica serovar typhi $O$ and $H$ antigens, the Salmonella enterica serovar paratyphi $\mathrm{AH}$ antigen and paratyphi $\mathrm{BH}$ antigen. In the present study an agglutination titer for $\mathrm{TO}-$ 1:20 is $28 \%$, for 1:40 is 24\%, followed by 1:80 and 1: 160 which is 10\%, 4\% respectively. The highest sample with an anti-H titre found with 1:20 (22\%) followed by 1:40(17\%). Based upon the results of the study it has been recommended that a single Widal can be significant in an endemic region when higher titre $(1: 160)$ is obtained.
\end{abstract}

Keywords: Baseline titre, Dehradun, Salmonella typhi, Typhoid fever, Widal.

\section{INTRODUCTION}

Enteric fever is endemic in developing country like India and it continues to be one of the major health problem here [1]. Typhoid fever is a systemic infection which is caused by the bacterium, Salmonella enterica serotype typhi. This highly adapted human specific pathogen has evolved remarkable mechanism for its persistence in its host that helps the organism to ensure its survival and transmission[2]. Enteric fever afflicts the local community and the travelers to the endemic areas. The incidence tends to be rise during the rainy season due to water logging and contamination of the water with sewage. The social factors that add to the enigma are the pollution of the drinking water supplies due to open air defecation, urination, contaminated food, personal hygiene, habits and poor health practices. The definite diagnosis of enteric fever in the patients with a compatible clinical picture is made on the basis of isolation of the Salmonella from blood, bone marrow, stool or urine and demonstration of the 4 fold rise in the antibody titer to both $\mathrm{O}$ and the $\mathrm{H}$ antigen of the organism between the acute and the convalescent phase [3].

In developing countries, facilities for isolation and culture are often not available especially in smaller hospitals, and diagnosis relies upon the clinical features of the disease and detection of agglutinating antibodies to $S$. typhi and S. paratyphi by Widal test. Classically four-fold rise of antibody in paired sera is considered diagnostic of typhoid fever [4]. But paired sera are often difficult to obtain and specific chemotherapy has to be instituted on the basis of a single Widal test [5]. The aim of the present study was to determine the baseline titer of healthy population of Dehradun city.

\section{Materials And Methods}

This prospective epidemiological cross sectional study was conducted in the Department of Microbiology, Shri Guru Ram Rai Institute of Health and Medical Sciences, Dehradun, India after taking ethical clearance from the Institute's Ethical committee. The non-repetitive samples were collected from 300 healthy adults (>18 years old) who were apparently free from disease and not vaccinated for typhoid and not had fever since last six months. In order to calculate baseline antibody titres against the $\mathrm{O}$ and $\mathrm{H}$ antigens of Salmonella enterica serovar Typhi/Paratyphi $A$ and B, tube agglutination method was adopted. The antigens used were from Span Diagnostics kit, GIDC, Sachin 394230 (Surat) India. Kit literature was strictly followed.

\section{Results}

A total of 300 healthy adult volunteers of different age, sex and socioeconomic groups were screened for the agglutination against Salmonella enterica subspecies enteric serotypes, Typhi, Paratyphi A and Paratyphi B. Majority of individuals screened belonged to 18 to 40 years age group (Table 1). A titre of $\geq 1 / 20$ for $\mathrm{O}$ and $\mathrm{H}$ was present in $67 \%$ and $50.3 \%$ of individuals respectively, while a titre of $\leq 1 / 20$ for $\mathrm{AH}$ and $\mathrm{BH}$ was $92.6 \%$ and $85 \%$ of individuals respectively (Table 2). Table 3 shows tube agglutination result of the same at different dilutions. 
Determination of baseline Widal titre among apparently healthy population in Dehradun City

Table 1 Age/gender wise distribution of samples

\begin{tabular}{ccc}
\hline $\begin{array}{c}\text { Age of the healthy } \\
\text { individual }\end{array}$ & $\begin{array}{c}\text { Total } \\
\text { received }\end{array}$ & samples \\
\hline $\mathbf{1 8 - 4 0}$ & & 282 \\
$\mathbf{> 4 0}$ & 18 \\
Gender & \\
Male & 176 \\
Female & 124 \\
\hline
\end{tabular}

Table 2 Distribution of samples with antibody titre against different serotypes

\begin{tabular}{llllll}
\hline Serotype & Antibody type & $\geq \mathbf{1 : 2 0}$ & $\mathbf{\%}$ & $\leq \mathbf{1 : 1 0}$ & $\mathbf{\%}$ \\
\hline Typhi & Anti O antigen & 201 & 67 & 99 & 33 \\
Typhi & Anti H antigen & 151 & 50.3 & 149 & 49.6 \\
Paratyphi A & Anti H antigen & 22 & 7.3 & 278 & 92.6 \\
Paratyphi B & Anti H antigen & 45 & 15 & 255 & 85 \\
\hline
\end{tabular}

Table 3 Tube agglutination result at different dilutions

\begin{tabular}{lcccc}
\hline Antigen titre & $\begin{array}{c}\mathbf{O} \\
(\boldsymbol{\%})\end{array}$ & $\begin{array}{c}\mathbf{H} \\
(\boldsymbol{\%})\end{array}$ & $\begin{array}{c}\mathbf{A H} \\
(\boldsymbol{\%})\end{array}$ & $\begin{array}{c}\text { BH } \\
(\boldsymbol{\%})\end{array}$ \\
\hline $\mathbf{1 : 2 0}$ & 84 & 66 & 14 & 20 \\
& $(28 \%)$ & $(22 \%)$ & $(4.6 \%)$ & $(6.6 \%)$ \\
$\mathbf{1 : 4 0}$ & 74 & 51 & 6 & 14 \\
& $(24.6 \%)$ & $(17 \%)$ & $(2 \%)$ & $(4.6 \%)$ \\
$\mathbf{1 : 8 0}$ & 31 & 23 & 2 & 10 \\
& $(10.3 \%)$ & $(7.6 \%)$ & $(0.6 \%)$ & $(3.33 \%)$ \\
$\mathbf{1 1 : 1 6 0}$ & 12 & 11 & 0 & 1 \\
& $(4 \%)$ & $(3.6 \%)$ & $(0 \%)$ & $(0.3 \%)$ \\
\hline
\end{tabular}

\section{Discussion}

Bacteriological culture remains the gold standard for definitive diagnosis of enteric fever. In an acute febrile illness in endemic typhoid region with ambiguous clinical picture, a rapid, accurate, specific and sensitive test should be used to differentiate typhoidal from non-typhoidal febrile illness [6]. However due to various constraints, in developing country like India we need an alternative test which is readily available, cheaper yet reliable. This makes widal agglutination test as the most common alternative laboratory procedure for the diagnosis of enteric fever. This test detects ' $\mathrm{O}$ ' and ' $\mathrm{H}$ ' antibodies against various Salmonella species . The $\mathrm{O}$ antigen is the somatic antigen and antibodies against the $\mathrm{O}$ antigen are predominantly $\operatorname{IgM}$ which rise early in the illness and disappear early. The $\mathrm{H}$ antigens are flagellar antigens of Salmonella typhi, paratyphi A and paratyphi $B$. Antibodies to $\mathrm{H}$ antigens are both $\operatorname{IgM}$ and $\operatorname{IgG}$ which rise late in the illness and persist for a longer time $[4,6]$. In endemic areas, baseline anti $\mathrm{O}$ and anti $\mathrm{H}$ antibodies are present in the population owing to repeated subclinical infections with Salmonella Typhi / Paratyphi [6]. These antibody titers vary with age, socio economic strata, urban or rural areas and prior immunization with the TAB vaccine [7]. The specific purpose of this study was to develop local recommendations for the interpretation of Widal test. In the present study an agglutination titer for TO $-1: 20$ is $28 \%$, for $1: 40$ is $24 \%$, followed by $1: 80$ and $1: 160$ is $10 \%$ and $4 \%$ respectively. The highest sample with an anti-H titre found with 1:20 followed by 1:40 [Table 3]. This study showed $94 \%$ of the samples with a titre which was equal to or less than 1 in 80 to $\mathrm{O}$ antigen and $92.7 \%$ samples had a titre which was equal to or less than 1 in 80 to the $\mathrm{H}$ antigen of Salmonella enteric serovar typhi. The distribution of 22 samples with an anti-AH titre of $\geq 1: 20$ was seen in 14 samples (4.6\%) and rest with an antiAH titre $\geq 1: 40$. Whereas the distribution of 45 samples with an anti-BH titre of $\geq 1: 20$ was seen in 20 samples $(6.6 \%)$ and $1: 40$ and $1: 80$ is $4.6 \%$ and $3.3 \%$ respectively. As $90 \%(20 / 22)$ and $75 \%(34 / 45)$ individual had a titre of $\leq 1: 40$ for the Salmonella enterica serovar paratyphy $A$ and $B$, anything above this can be taken as diagnostic titre in this area[8].

Various Indian studies showed the baseline titre of 1:80 for $\mathrm{O}$ antigen $[1,8,9]$ and same with anti- $\mathrm{H}$ agglutination [8,9] where as Pal et al., has documented significant titre of 1:40 for $\mathrm{O}$ and 1:80 for $\mathrm{H}$ antigen [3].

Punia et al., concluded in his studies that titers of 160 for anti-O and 320 for anti-H for enteric fever in Chandigarh [1]. The variation depends on the degree to which the enteric fever is endemic in each area a fact which may change over time. Hence this needs to be updated from time to time. In our study $4 \%$ of healthy population has shown titre of 1:160 for $\mathrm{O}$ antigen and 3.6\% population shown agglutination against $\mathrm{H}$-antigen. 
Therefore 1 in 160 or above would be considered as significant and indicative of enteric fever if repeat sample is not available.

\section{CONCLUSION}

As in endemic areas population is permanently "immunologically sensitized" due to constant exposure, the response to infection is more rapid and reaches higher levels [10]. We may thus conclude that, despite the fact that knowledge of baseline titre of a region may help in the interpretation for diagnosis of typhoid fever, a single Widal can be significant in an endemic region when higher titre (1:160) is obtained.

\section{References}

[1] Punia JN, Joshi RM, Gupta V, Arora RK. Determination of the baseline Widal titre in Chandigarh. Ind. Journal of Medical Microbiology. 2003; 21 (2): 144

[2] Parry CM, Hoa NT, Diep TS, Wain J, Chinh NT, Vinh H, et al. The value of a single tube Widal test in the diagnosis of typhoid fever in Vietnam. J of Clin Micro. 1999; 37(9): 2882-85.

[3] Pal S, Prakash R, Juyal D, Sharma N, Rana A, Negi S. The Baseline Widal Titre Among the Healthy Individuals of the Hilly Areas in the Garhwal Region of Uttarakhand, India. J of Clinical and Diagnostic Research. 2013; 7(3): 437-440.

[4] Freeman R. Bacterial immunoserology, in (10 Ed), Topley and Wilson's Microbiology and Microbial infections ( ASM Press. USA. Edward Arnold Publishers Limited.2005) 744.

[5] Alam ABMS, Ahmed FR, Chaiti F. Utility of A Single Widal Test in The Diagnosis of Typhoid Fever. Bangladesh J Child Health 2011; 35 (2):53-58.

[6] Olopoinea LA, King AL. Widal agglutination test- 100 years later: still plagued by controversy. Postgrad Med. J. 2000; 76:80-84.

[7] Shukla S, Patel B, Chitnis DS. 100 years of WIDAL test and its reappraisal in an endemic area. Indian J Med Res. 1997; 105: 5357.

[8] Patil AM, Kulkarni ML, Kulkarni AM. The baseline Widal titre in healthy children. Ind. J. Paed. $2007 ;$ 74: 1081-83.

[9] Prashant Peshattiwar. Study of the Baseline Widal Titre Amongst Healthy Individuals in Amlapuram, Indian Journal of Clinical and Diagnostic Research. 2012; 6(3):416-417.

[10] Pang T, Puthucheary SD. Significance and value of the Widal test in the diagnosis of typhoid fever in an endemic area. J. Clin. Pathol 1983;36: 471-75. 